\title{
Southern Studies as Area Studies: Faulkner and Provincial Nationalism during the Cold War
}

\section{Jordan Dominy}

Through a reexamination of William Faulkner's well-documented critical recovery at the hands of New Critics in the 1940s and early 1950s as an event integral to the formalization of both American literary studies and southern literary studies, this article argues that the advent of southern studies can best be understood as the application of area studies to the study of regional literature and culture within the United States and a nationalistic project of the Cold War. In order to understand the role Faulkner plays in this process, this article examines his prominence in Louis D. Rubin, Jr. and Robert D. Jacobs's volume of literary criticism, Southern Renascence: The Literature of the Modern South (1953), and closely read for political and social commentary in Faulkner's novel, Intruder in the Dust (1948), which will be read as Faulkner's own commentary on the new area studies of the US South. Faulkner is an important figure for understanding southern studies as area studies because of his inescapable associations with regional literature and the ease with which he is interpreted as an author concerned with morality and individualism. Formalist scholars transformed him from an author of regional oddity and the literature of his region into subjects of national import because they were able to identify parallels between the South's racial conundrums and the moral challenges facing American democracy in light of Soviet diplomatic ambitions. In this manner, Faulkner became important to the American modernist canon and formed a way by which the recovery of his work could be extended to an entire southern liter- 
ary canon, making the study of southern literature simultaneously a provincial and nationalistic project.

Indeed, few would dispute Faulkner's importance to the southern or American literary canon but he serves as an important figure in my argument about the formation of southern literary studies, not because he is a prototypical southern writer or because southern literature began with him, though this is the mythology that developed around him in the final decade of his life. Rather, Faulkner appears in the canon as a key figure among the development of southern literary studies because his work served the same important political and ideological purposes for formalist intellectuals, especially New Critics. Moreover, even Faulkner's own work engaged the notion of American exceptionalism through southern exceptionalism, the ideological causes that required a southern area studies. This is the starting point for Lawrence H. Schwartz's study Creating Faulkner's Reputation (1988). While Malcolm Cowley and others would argue that Faulkner became great because he is a literary genius who would eventually have attained proper honors, Schwartz counters that Faulkner "became one of the beneficiaries of an aesthetic created by an intellectual elite committed to the survival and preeminence of the United States." During what Frederic Jameson identifies as the late modernist moment, ${ }^{2}$ both New Critics and the New York Intellectuals recuperated Faulkner from his prior reputation-a realist author countering modern society with tales of the barbaric, violent, and corrupt South - to a modernist literary master dealing with the moral challenges of an irrational, modern world and as key as T. S. Eliot and Jackson Pollock, whose achievements were products of the "preservation of freedom of expression under the democratic traditions of the West." 3 What happens to Faulkner and southern literature during this time is parallel to what happens to abstract expressionism, as told by Serge Guilbaut. ${ }^{4}$ Rather than a school of art, though, intellectuals turned to a regional literature in which they could identify a useful aesthetic and divorce it from all political contexts and weed out unsavory political positions associated with the far left, socialism, and Marxism. This interest in the rehabilitation of Faulkner begins at the time, Schwartz explains, when scholars interested in southern literature were looking for "a great literature rooted in the regional consciousness, but one that also transcended provincial nationalism to achieve universality." Faulkner provided just such a convenient New Critical paradox - simultaneous concern for humanity and the peculiar customs of the US South. His distance from "literary radicalism" in the 1930s and containment of history and current events made him politically safe compared to leftist authors, such as John Steinbeck. ${ }^{6}$ Rather than endorsing the New Deal, associating with suspected Marxists, and encouraging collectivism, Faulkner's perceived southernness emphasized a rugged, sacred individualism and self-determination that was the centerpiece of America's arsenal in the cultural Cold War.

While Schwartz is concerned mainly with Faulkner, I offer a corollary to his argument regarding how Faulkner's recuperation affects the formal study of 
southern letters. I argue that focusing on Faulkner as an exemplary American writer also raises the question of exemplary southern literature and writers and their relationship to the national canon, providing a pathway to formalizing southern studies. The result is southern literary studies as a peculiar manifestation of area studies - not a regional genre - within which unsavory elements of American democracy could be housed as moral problems as opposed to political challenges tarnishing America's image abroad. As Carl E. Pletsch notes, area studies are "academic specialties created during the Cold War to supply governments with advice about policy making." " Generally, these academic specialties "correspond to the new areas of political and economic influence being sought by the United States" during the 1950s ${ }^{8}$ : African studies, European studies, and Asian studies are all key examples. I am not proposing that southern studies formed as a way for the US government to better understand how to exert its influence within the South; rather, I propose that southern studies as it was initially practiced was a way for literary critics to better understand America's newfound hegemony and achieve through other authors beyond Faulkner a particular goal: provincial nationalism achieving universality. Organizing a southern literature becomes a way to demonstrate that course. There has been much scholarship identifying problems in the ways the "South," southern literature, and southern culture have been studied and defined and also coming to understand the region not just within the context of the United States but within hemispheric and global contexts as well. ${ }^{9}$ I further suggest that the inception of formal southern literary studies as the segment of national literature containing America's problems also indicates global contexts because it equipped warriors fighting in the cultural Cold War to better understand the challenges facing American democracy abroad and to counter Soviet attacks on the unsavory political elements of American society.

Thomas Borstelmann argues that going into the postwar period, the greatest foreign policy issue facing the United States was a domestic problem: the existence of segregation among its own peoples while attempting to spread democracy abroad to areas formerly under colonial rule, especially Africa. The Soviet Union told the colonized world that the United States would bring Jim Crow with their money everywhere they went, and US tolerance of European colonialism in Africa was due mainly to racial ideas that were held in common between Europe and the United States. ${ }^{10}$ American attitudes about race became scrutinized in the international arena, and after World War II efforts were made to shove Jim Crow to the fringes of American society (i.e., locate it only in the South). Nevertheless, racial violence in the South went overnight from being local news rarely heard to big international headlines. "The elemental problem for America's first Cold Warriors in dealing with race," Borstelmann says, "was their inability to wall off white American racial attitudes and practices from the rest of the world and its nonwhite majority." literature, though, allows just that: literary works portraying racism in which ultimately democratic and American ideals supersede these problems from the 
real political situation facing the United States during the Cold War. Through the lens of southern studies as area studies, the peculiar ethical challenges of the South paralleled in a less immediately dangerous way America's challenges abroad. Segregation became, in Leigh Anne Duck's explanation, a temporal and cultural difference within American literature beyond the purview of national and, by extrapolation, international law. ${ }^{12}$

Faulkner realized that his work and southern literature could be mobilized to support democracy on all stages of the Cold War, and he sometimes participated in this mobilization. His understandings of literature's ethical influence is perhaps nowhere more clear than in his Nobel acceptance speech:

I believe that man will not merely endure: he will prevail. . . . The poet's, the writer's, duty is to write about these things. It is his privilege to help man endure by lifting his heart, by reminding him of the courage and honor and hope and pride and compassion and pity and sacrifice which have been the glory of his past. The poet's voice need not merely be the record of man, it can be one of the props, the pillars to help him endure and prevail. ${ }^{13}$

His writing and others' could be not merely an account of (we can assume a distinctly westernized) humanity but a key element in its survival through reinforcing values - courage, honor, hope, pride, and so on. Later in his life as a Cold Warrior, though, in 1956, Faulkner wrote to David Kirk, "There are seventeen million Negroes [in the United States]. Let us have them on our side, rather than on that of Russia," ${ }^{\prime 14}$ indicating that a turn toward communism because of its integrationist sympathies was an outcome he thought plausible and one he wished to avoid, implying that blacks should be appeased only so that they do not become communists. ${ }^{15}$ But the larger vision underlying his comment to Kirk applies to the Cold War function of southern literature; in understanding the conflict between the South's minorities and their oppressors, the United States could better understand its new role as the primary disciple of democracy among nations newly freed from colonial rule.

\section{Imagining a Renascence}

With Faulkner as the author around whom southern area studies becomes organized, Louis D. Rubin, Jr. and Robert D. Jacobs emerge as primary critics organizing it. Fred Hobson calls Southern Renascence: The Literature of the Modern South, the volume of essays Rubin and Jacobs edited, "the origins of modern southern literature as an academic discipline." ${ }^{16}$ Michael Kreyling echoes that sentiment specifically about Rubin's career, saying, "Few will dispute the claim that Rubin is the primary architect and developer of southern literary study" in the twentieth century. ${ }^{17}$ The clearest marker of Rubin's agenda 
for southern literature is a stringent formalism (which emphasizes interpretation based on analysis of form and aesthetic over content and context) through which he plays, as Kreyling describes, guardian of the southern canon, preserving the vision held by the twelve Nashville Agrarians in I'll Take My Stand (1930): a South without its explicit political trappings, namely, racism. ${ }^{18}$ Yet the real import of Rubin's interpretive balancing act between the South's history and its literature is that he seems to have a certain purpose in mind for the field: area studies of the South. The preface to Southern Renascence explains that he and Jacobs originally had the idea for the volume as a special issue of the Hopkins Review. After gauging the response to the special issue proposal, "it was realized just how widespread was the latent interest in Southern writing, and how potentially important a thoroughgoing survey and analysis of the literature of the modern South might be" (emphasis added). ${ }^{19}$ Rubin and Jacobs indicate that there has been a present but undeveloped critical interest for the literature of the US South. Presumably, this latent interest was among their formalist colleagues in literary criticism; I argue that this suggests that literary critics, busily positioning America's national literature as the best artistic examples for the free world, saw potential for but did not realize how southern literature fit into any nationalist canon. Rubin and Jacobs help to provide just that by leveraging Faulkner into their area studies of the South, acknowledging in their preface that they seek to provide southern literary studies as a way for these scholars to better understand American literature.

Faulkner is the most important figure for authors in Rubin and Jacobs's project, but also significant are correlations drawn between themes explored by other white southern writers and the national zeitgeist of the Cold War. Walter Sullivan, in his contribution, argues that a recurring theme in southern fiction is the Civil War's disturbance of the moral concurrence of the public and private spheres, in which the traditional family falters. ${ }^{20} \mathrm{He}$ additionally states, in direct reference to Faulkner's opus,

Because in the Old South the honor and the pride were there, not as individual virtues in isolated men, but as a part of the public consciousness, the moral basis on which the culture was constructed. This is the reason that the War has been used so often by so many Southern writers. It is the grand image of the novelist, the period when the "ultimate truths" with which Mr. Faulkner says the writer must deal, existed as commonly recognized values within a social framework. It is the only moment in American history when a completely developed national ethic was brought to a dramatic crisis. ${ }^{21}$ (emphasis added)

Sullivan's explication of the southern writer's relationship to the Civil War certainly fits what has been a cornerstone of southern studies, yet he presents his 
version of the southern experience and understanding of history and ethics as commensurate with the national experience. From this point, it follows that southern literature elucidates for its scholars how a commonly held morality centered on pride and honor confronts and endures a challenge to its supremacy. In Sullivan's depiction, comparisons beg to be drawn between the common southern ethic and a similar American ethic developing during the Cold War: belief in God in the face of godless communism, the self-determination of the individual, and the nuclear family. The implication is that scholars could learn from southern literature's portrayals of its ethical and moral challenges (the simultaneously political problem of slavery, for example) and its confrontation with crisis how best to promulgate and protect America's democratic ethic abroad in an equally precarious and challenging climate.

Of particular importance to the collection is an essay by a figure who would play a significant role in the shaping of southern studies. C. Vann Woodward, then a professor of history at Johns Hopkins, contributed his well-known essay "The Irony of Southern History" to Southern Renascence. In it, Woodward argues that studying the South as an "eccentric" segment of the United States is important not because doing so will enhance our understanding of the South, "for from a broader point of view it is not the South but America that is unique among the peoples of the world. This eccentricity arises out of the American legend of success and victory, a legend that is not shared by any other people of the civilized word." ${ }^{22}$ In addition to situating his argument within the experiences of white southerners, his comment suggests that the study of the South and its literature is paramount for the comprehension of America's leadership of the free world at the end of World War II. In order to make that connection, he draws parallels between the economic situation facing the United States in the 1950 s and that of the US South during the nineteenth century, as well as comparing the world opposition and resentment of American successes with southern attitudes about its defeat in the Civil War. Most powerful and significant in his essay, however, is his comment about what history is and where the history of America is located. Early on, Woodward comments that history is commonly regarded as the bad things that happen to other people, implying that America's history has been obscured by the comparison of Europe's recent turmoil with the legendary status of the founders and Revolutionary War heroes. Moreover, the comment implies that because most Americans have not suffered a major military defeat and the world wars were not fought in North America, they are disconnected from their history, as opposed to southerners who did suffer military defeat and Europeans who witnessed war firsthand. He declares, "With all her terrible power and new responsibilities combined with her illusions of innocence and her legends of immunity from frustration and defeat, America stands in greater need that she ever did of understanding her own history." ${ }^{\prime 23}$ He ultimately proposes in "The Irony of Southern History" that the way for Americans to connect to their history is to study the South because southerners know from firsthand experience that "history has happened to our people in our 
part of the world." 24 The United States can best understand how to lead the free world and its own precarious position of power through the South's historical circumstances and literature.

Where Woodward's essay calls for a greater emphasis on studying the history of the South - which could be extrapolated as part of the emerging area studies of the South - the rest of Rubin and Jacobs's book answers it. As the clearest guiding principle of the book, the call is answered by studying the South through the lens of William Faulkner's opus and the circumstances of its composition. Faulkner is the primary focus of five individual essays and appears as a point of comparison in nearly every other entry in section III, "Novelists of the South," and in all four pieces in section II, "The Themes of Southern Literature." (In contrast, Robert Penn Warren and his fiction are the focus of only two essays.) Rubin and Jacobs make this explicit in their editor's note to a symposium, which opens the second section, "The Themes of Southern Literature." It features the sociologists Howard W. Odum and John MacLachlan, and in their note the editors emphasize a question posed by Donald Davidson in an address to Mississippi State College in 1950:

I turn to sociology and ask whether it can account for the appearance in Mississippi, of all places, of William Faulkner, in the three decades between 1920 and 1950. . . . Can sociology also explain why William Faulkner, or some novelist of comparative stature, did not appear, during this period, somewhere north of the Ohio - say, in Massachusetts or Wisconsin? ${ }^{25}$

In hindsight, Davidson's pondering seems a little preposterous, unanswerable outside of intangible speculation and perhaps irrelevant, yet it raises "a root question," according to Rubin and Jacobs, "one which must be thoroughly considered in any serious attempt to understand the modern literature produced by Southerners." 26 Their use of Davidson's question as a key point of inquiry bears a couple of significant implications for Southern Renascence. It more pointedly than other passages of the collection establishes an area studies project, especially in Davidson's call for sociology - a discipline closely associated with other area studies - to answer what was for scholars at the height of renewed interest in Faulkner's work a burning question. Most important, the question all at once binds together the perceived supremacy of Southern Regionalism, the hegemonic aspirations of American national literature, and the figure of William Faulkner.

Yet Odum seems dubious regarding Davidson's question. In his contribution to the seminar, he casts doubt on whether Faulkner's southernness has anything to do with his greatness. Odum addresses the problems with Davidson's understanding of sociology, then explores how different variables-socioeconomic, political, and otherwise - could be construed as factors in not only 
Faulkner's southern origins but also the origins of any other author from the South or other US region. He even mentions the literary importance of H. L. Mencken, whose influences within the publishing industry opened the door for many southerners. ${ }^{27}$ His co-respondent, MacLachlan, on the other hand, readily accepts Davidson's assertion that the South has something to do with Faulkner's greatness. In "No Faulkner in Metropolis," he contends that Faulkner's familiarity with the rural allowed him in his fiction to create a place, unlike urban landscapes, where "there is nothing between its folk and the elemental forces of the universe, no canopies, walls, clinics, ranks of professionals and bureaucrats to stand between them and life and death." ${ }^{28}$ The distinction between Odum and MacLachlan's response is important precisely because the former provides a coy critique in highlighting the challenges sociology faces in undertaking such a question, whereas the latter unquestioningly embraces southern exceptionalism and area studies of the South as the best method for understanding the primitive needs of individuals during modern times.

Race does not take center stage in the area studies formulation of Southern Renascence until Irene C. Edmonds's "Faulkner and the Black Shadow," which is its last essay directly addressing southern studies' founding figure and the only essay written by a black scholar for the collection. (Rubin included his former student in the collection despite resistance. ${ }^{29}$ Regardless, his gesture toward inclusivity did not prevent his collection from being charged with "parochialism and special pleading." ${ }^{30}$ ) She begins her essay by quoting Shreve McCannon, who implores his roommate at Harvard, Quentin Compson, to tell about the South in Absalom, Absalom! (1936). Her essay seems to stand in for Quentin's response; Edmonds indicates in her consideration of black characters in Faulkner's work that understanding blacks and their relationship with their oppressors is vital to understanding the South. She declares that the South's fall has roots not so much in "a death struggle between decadent Sartorises and materialistic Snopeses" as in claiming to be Christian yet not behaving as such, particularly in regard to race relations. ${ }^{31}$ Faulkner rarely attempted such an understanding, she argues, pointing to Lucas Beauchamp of Go Down, Moses (1942) and Intruder in the Dust as the only black character whose inner thoughts are revealed through narration. ${ }^{32}$ However, Edmonds's incisive critique does not so much present how Faulkner's presentation of race could be a model for intellectuals grappling with racial discord in the United States as as it does demonstrate how best to avoid a treatment of the problem altogether. In pointing to disparities between the character of Dilsey in The Sound and the Fury (1929) and the strong-willed Lucas Beauchamp in Intruder in the Dust, Edmonds concludes that Faulkner's fiction as a whole does not contribute a solution to the race question in the South. And even though she concludes that Faulkner deems slavery the cause of the South's failure, she says, "What Faulkner has done is to present situations and reserve any personal judgment. He does not write social protest." ${ }^{33}$ So if the archetypal author of southern lit- 
erature and culture takes no activist stance on improving conditions for minorities in the South, why should its scholars and intellectuals?

It is precisely this kind of formalist posturing that Southern Renascence features: praising works by framing their significance within questions of aesthetics, morality, internal conflict, or individual worth as it relates to a grand American society modeled on Faulkner's Yoknapatawpha County, the fictional setting for many of his novels and microcosm of idealized southernness rather than addressing any collectivist or progressive narrative advocating change within the real world. While it does devote essays to other authors in its pages, the figure of Faulkner is what makes possible the area studies paradigm of southern studies. This is significant not only for southern studies but for Faulkner as well, who was alive and witnessing this mobilization of his novels and stories and found himself in a position to participate in it.

\section{Blowing Smoke}

A critical project such as Rubin and Jacobs's, therefore, bears significance not only for the development of southern area studies and Faulkner's critical history but for his own attitude toward the South as well. Without a doubt, Faulkner felt the intellectual pressures that scholars of the emerging canons of American and southern literature placed upon him. Frequently an audience to interpretations - political or otherwise - of his own works, he maintained a distance. Kreyling argues that "Faulkner had few or partially formed ideas and judgments on many of these issues, and he was normally reluctant to divulge, and never willing to debate, most of them," requiring a critical "fabrication" of the larger-than-life figure, "Faulkner." ${ }^{34}$ Kreyling further comments, "William Faulkner was sincere when he said he wanted anonymity, that he resented imprisonment in the role of representative author, that his later work is marked by the desire to unwrite or subvert his public image." ${ }^{35}$ On the other hand, Intruder in the Dust, a novel from just past the midpoint of his career, assists in the formulation of Kreyling's "Faulkner" and southern area studies rather than separating the individual Faulkner from the public figure of "Faulkner." It does so in its representation of racism facing the United States and the South after World War II and its suggested solutions.

Intruder in the Dust is a departure from Faulkner's previous work in both genre and direct political content. Faulkner himself referred to it as a "mysterymurder." ${ }^{36}$ Moreover, Faulkner's main motivation for writing it seem mostly financial; he asked agent Harold Ober to seek magazine serial publication to maximize his profits on the manuscript, even acknowledging that he could leave out a chapter to make it more suitable for "popular consumption.." ${ }^{37} \mathrm{Be}-$ yond its detective story form being a departure from earlier work, Intruder is also a variation in that the novel not only serves as a case history on the nascent civil rights struggles, but also provides pointed commentary on solutions to the problems in contemporary southern race relations. Prior works certainly ad- 
dress race relations - even Gavin Stevens speaks about race in Light in August (1932) - but usually in a summative, descriptive manner as opposed to prescriptive: Shreve McCannon speculates at the end of Absalom, Absalom! that blacks will "conquer the western hemisphere" through racial assimilation, ${ }^{38}$ and Ike McCaslin in Go Down, Moses proclaims the South cursed for slavery and land ownership. ${ }^{39}$ It's not until Intruder in the Dust, however, that any character proposes solutions to the real world problem of racism and deliberately casts the problem as anything but a political problem.

Intruder centers on Lucas Beauchamp, a black man who frustrates the folks in the fictional Yoknapatawpha County because he has white ancestors and refuses to behave in the way blacks were expected to in the 1940s. Lucas is wrongly arrested for the murder of Vinson Gowrie. At Lucas's request, the sixteen-year-old Charles "Chick" Mallison and his childhood friend Aleck Sander search for evidence of the real murderer. Their efforts exonerate Lucas, whose legal representation, Gavin Stevens, Chick's uncle, is barely a party to the activities. Its early reviewers immediately noticed a political tinge in the novel. Calling the novel a "tract," Edmund Wilson, in his frequently cited 1948 review, surmises that Intruder "seems to have been partly inspired by the crisis at the time of the recent war in the relations between white and Negroes and by the recently proposed legislation for guaranteeing Negro rights. ${ }^{{ }^{40}}$ Yet few later critics who refer to Wilson go on to include his more polemical comment on Lucas's rescue from the lynch mob. He says of the would-be lynchers leaving in their cars to return to Beat Four, the community in the outlying areas of Yoknapatawpha County where the murder took place, "There has been nothing so exhilarating in its way since the triumphs of the Communist-led workers in the early Soviet films." ${ }^{\prime 1}$ The description importantly compares Intruder with propagandistic art, framing the coalition of Chick, Aleck, Stevens, and Miss Habersham (a spinster who assists Chick and Aleck) as having specific collective, political aims beyond simply rescuing Lucas. Wilson is not alone in detecting the political content of Faulkner's detective novel. Another early reviewer, Elizabeth Hardwick, perceives Gavin Stevens's expressed views on the race issue to be nothing more than a "want [of] violence in order to prove themselves right" that immediate integration would cause more harm than good. ${ }^{42}$ She, too, evokes Cold War apprehensions, suggesting that the position held by Intruder could cause the continued popularity of communism among African Americans.

Some years later, however, Cleanth Brooks, in the first extensive scholarly treatment of Intruder, discounts both Wilson's and Hardwick's political readings of the novel. Being the consummate New Critic, Brooks could not accept a simple dismissal of the novel as political, for doing so acknowledges political content. "A more cogent objection to this novel," he declares, "is the incoherence of the plot," an incoherence intensified by lengthy, politicized speeches. ${ }^{43}$ Alternatively, Brooks reads Intruder as story of a boy growing into a man through a conflict with his community. Chick's own ethical compass, 
which spurs him to accept Lucas's request and extend justice and equality to Lucas, steers him through the storm of racial discontent. Stevens's ramblings are, in Brooks's understanding of Intruder, "subordinate to the main matter: Charles Mallison's development toward wider sympathies and a sharper ethical conscience." ${ }^{44}$ Such a reading of Chick's moral individuality as the solution to what is really a rampant political problem within the South is not only a classic New Critical perspective, but also another move offering a palliative for racial unrest that does not solve the underlying issues of racial oppression (such as the poverty and vigilantism of the Beat Four lynch mob).

Most scholars regard Intruder as one of Faulkner's lesser works, perhaps following Brooks's lead, citing Stevens's moralizing speeches as poorly connected to the narrative. Jean E. Graham suggests that there is a double standard applied to Intruder in the Dust. Other characters-Quentin Compson and Jason in The Sound and the Fury are Graham's examples - have extended dialogues guilty of the same transgressions levied against Stevens, yet there is no prevalent dismissal of them as characters in the scholarship..$^{45}$ Graham ultimately argues for Stevens's importance to the novel as a tutor attempting to instruct his nephew concerning their southern community's long-held racism. The interaction between the two results in a complex dialogue between uncle and nephew. To dismiss the novel altogether on the basis of Gavin Stevens is, I concur, a terrible mistake and a great irony. Stevens's pontificating is what makes Intruder at the same time a significant point of departure for Faulkner (no character of his before so directly addressed current events) and a difficult text for literary scholars of his day to deal with. The novel presents Faulkner's understanding of how the South during the Cold War fit the discussion taken up by critics such as Rubin, Jacobs, and Brooks who founded formalized southern studies, yet it is this same school of criticism that passed over the novel because it was too overtly political.

The keys to this are, of course, Stevens's long monologues, which fall short of any kind of meaningful action. Such comes to light even better when considering Faulkner's own description of Stevens in an October 1948 conversation about Intruder with Malcolm Cowley during a visit at Cowley's home. According to published notes Cowley scribbled down about the visit after Faulkner's departure, "Stevens, he explained, was not speaking for the author, but for the best type of liberal Southerners; that is how they feel about Negroes. 'If the race problem were just left to the children,' Faulkner told me, 'they'd be solved soon enough." ${ }^{46}$ The latter assertion plays out in the pages of Intruder, for it is through the efforts of young Chick and Aleck (assisted by the spinster, Miss Habersham) that Lucas is exonerated and certainly not through any lawyering or philosophical waxing on Stevens's part. As Noel Polk explains it, Stevens is mostly a smoke blower. Polk points to the number of times he lights his corncob pipe at the end of speeches and in the way he reaches for the offensive abstraction "Sambo" when addressing the broad issues of the race problems as opposed to actually naming his client, Lucas Beauchamp, and addressing legal 
methods by which he may be defended. ${ }^{47}$ Moreover, Intruder was not the first time Stevens appears in Faulkner's work to speak about race. Near the end of Light in August, Stevens, the district attorney described as a "Harvard graduate, a Phi Beta Kappa," makes a brief appearance to provide commentary on the lynching of Joe Christmas, a man of uncertain racial origins accused of murdering a white woman. ${ }^{48} \mathrm{He}$ concludes that the root cause of Christmas's troubled past and violent demise is the dueling sensibilities and identities within him caused by the simultaneous presence of white and black blood and suggesting an antimiscegenation stance. ${ }^{49}$ Even here, when he does not address the import of racial tensions for the South or even the whole nation, he seems a man of lofty ideals, not meaningful action.

In spite of his denial to Cowley that Stevens spoke for him, the character has long been regarded as Faulkner's political mouthpiece. More importantly, Steven's commentary in Intruder serves as an instrument of southern area studies: a critical framework for understanding southern racial redemption that obscures and depoliticizes the problem by emphasizing individual moral responsibility and duty to country. If not outwardly, his statements support certain values key to American ambitions for global democracy during the Cold War. Most telling are Stevens's claims about American "homogeneity," which he tells Chick they are defending as opposed to tradition or "politics or beliefs." alone, for "the rest of the country has had to surrender voluntarily more and more of its personal and private liberty in order to continue to afford the United States. And of course we will continue to defend it [homogeneity]. ${ }^{51}$ Here through Stevens, Faulkner reveals and endorses one of the great paradoxes of Southern political sensibilities of the twentieth century: individual, provincial pride and homogeneity is something to which the entire US should aspire. For "only a few of us know that only from homogeneity come anything of a people or for a people of durable and lasting value - the literature, the art, the science, that minimum of government and police which is the meaning of freedom and liberty, and perhaps most valuable of all a national character worth anything in a crisis." ${ }^{2}$ If democratic art is what Cold War intellectuals seek to enable in the US fight against the contagion of communism, then the South ostensibly has all this to offer. But what manner of homogeneity?

This reasoning appears again in Stevens's argument about northern interference in the race question. He phrases it simply in his famous statement toward the end of Intruder in the Dust: "I only say that the injustice is ours, the South's. We must expatiate and abolish it ourselves, alone and without help or even (with thanks) advice." ${ }^{33}$ Yet Stevens's equivocation of racial homogeneity and cultural or moral homogeneity becomes clear when this statement is compared with his earlier comments:

We- he [Sambo, not Lucas Beauchamp] and us [white southerners] - should confederate: swap him the rest of the economic and political and cultural privileges which are his 
right, for the reversion of his capacity to wait and endure and survive. Then we would prevail; together we would dominate the United States; we would present a front not only impregnable but not even to be threatened by a mass of people who no longer have anything in common save a frantic greed for money and a basic fear of failure of national character which they hid from one another behind a loud lipservice to a flag. ${ }^{54}$

It is preposterous, of course, to suggest that contentious racial relations over hundreds of years built character among white and black southerners and that their differences can be solved once and for all through an economy of generosity: white southerners give black southerners their rights in exchange for all the brutality endured. Yet Stevens's claim here does suggest dual meanings for the homogeneity the rest of the country lacks: a separation of equal races that remain homogeneous and a moral homogeneity valuing individual resolve and national pride that crosses race and geographic region within the United States. Joe Karaganis assists in clarifying that in Stevens's logic, the protection of this homogeneity is crucial for the protection of the United States. Furthermore, he claims "Confederation, in this respect, is not just a regional solution to the race question, but a model of national redemption in which the white South stands, unexpectedly, in the vanguard"55 (emphasis in the original). Karaganis's presentation of Stevens's assertions presents this confederation as southern area studies: the South leads with a model for the best management of national — and international-tensions.

In the foregoing comment from Stevens, he places the impetus for change with willing individuals - in the novel his nephew and Aleck - rather than the object of his criticism, a "mass of people" bound together by only business interests and national pride. Given such emphasis, Stevens's principal declaration in Intruder is - and Karaganis agrees - that individuals are necessary as opposed to any collective effort to make material changes to race relations in the South and the United States. Progress begins with an individual and spreads virally ${ }^{56}$ His model is, therefore, not one of collectivity, which would be too closely associated with communism during the Cold War. Here Faulkner divulges one of his great political fears within his art. Polk notes that the notion of any group acting collectively, in Faulkner's mind and the collective conscious of Cold War intellectuals, is unappealing precisely because collectivism most frequently manifested itself as communism after World War II. This also applied to the new government programs that “in Faulkner's view, were depriving individual man of his capacity and of his right to depend upon himself." ${ }^{57}$ Stevens's lectures may be nothing but smoke blown at Chick, but these lengthy talks suggest more broadly what southerners and Americans can do to combat these unsavory political developments in the United States and abroad. Polk further explains, 
Southern whites and blacks, he [Faulkner through Stevens] argued, had more in common with each other than any Southerner had with any Northerner; therefore, Southerners, black and white, had better stick together to stave off any outsider's challenge to their way of life. By the same token, he felt all Americans, black, white, southern, northern, needed to stick together in order to present a united front to combat the menace of Communism. ${ }^{58}$

Faulkner's vehement anticommunism as a context for Intruder is important for two reasons. First, the novel does, in this light, transmit Faulkner's political sensibilities regarding issues newsworthy in 1948: racial oppression and communism. Moreover, prominent black authors of the time, Richard Wright, Langston Hughes, and Ralph Ellison, held various associations with the Communist Party. Second, it shows how Faulkner's sensibilities are complicit in Rubin and his fellow New Critics organization of the nascent southern studies: America can learn how best to contain its political ills by watching how the South labors to contain its own. Intruder becomes a literary text contributing to area studies of the US South.

One of the aforementioned reviews of the novel also notes these area studies gestures: Elizabeth Hardwick's excoriating review. "The sickness of Intruder in the Dust, the fear and despair," which she sees driving the political agenda of southern resolve in solving its own shortcomings,

are intimately connected with the future of Faulkner's career, a career which demands that there be a South, not just a geographical section and an accent, but a reasonably autonomous unit, a kind of family ready, and even with a measure of geniality, to admit the existence of the people next door and to cooperate in the necessary civic responsibilities, . . . but beyond that unique and separate, not to be reproached, advised, or mourned for the goings on behind the door. ${ }^{59}$ (emphasis added)

A double entendre can be read in Hardwick's statement. Initially, she seems to say that a career such as Faulkner's required there to be a South to use as subject matter. (To say that Faulkner's career would not exist without the South is, perhaps, reason enough to be run out on a rail from English departments given the sheer quantity and depth of scholarship produced on his work and life.) Of greater consequence is the second interpretation of Hardwick's remark and what I believe she intends: Faulkner's career and the study of it command that there be a South. His works foster the theorization of the South as a discrete unit for twentieth-century historical and sociological study (if even in the very least by way of Donald Davidson's misguided question that Howard Odum 
was forced to answer) and the formal study of its literature (for which Faulkner has been taken as the supreme example and starting point). And in the case of Intruder, the South must maintain its independence by being allowed to lead itself to whatever destiny after a sordid and brutal history of racial injustice, even if that includes the secret hope for violence in order to prove all nonsouthern meddlers wrong. But because of the entangled, unique history of white and black in Faulkner's South, it can lead the way as the model for the management of such tensions.

\section{Faulkner as "Faulkner"}

William Faulkner never escaped the "Faulkner" figuration posited by Kreyling, and neither Intruder nor the increased amount of attention his work would receive in the years following his Nobel win and prominence in Southern Renascence would assist him in gaining any more distance from it. Instead, Faulkner became not only the rallying point but also a participant in the founding of southern literary studies as an area studies by which intellectuals better understood what it meant to be American - to value tradition, history, and the individual's moral initiative and ingenuity for solving problems and to be uninvolved in the affairs of others (or at least maintain the appearance of being uninvolved) - and how to further contain unsavory, national political problems by making them into an object of formalistic literary study. The emerging southern area studies enable the "color-blind myths of American innocence" in which racial unrest and the civil rights movement happened only in the South, where it does not harm narratives of exceptional American leadership during the Cold War. ${ }^{60}$

In the wake of the emerging southern studies, the South's unwavering selfdeterminism seems to influence the United States in its dealings with European allies regarding its colonial holdings. Borstelmann recounts that in order to maintain good working relationships and free commerce with European nations and their colonies, the United States allowed its distaste for outside rule (akin to the South's distaste for meddling) to slow down its pressing for colonial independence even as its own cultural influence expanded. ${ }^{61}$ During the 1950 s with President Eisenhower and his administration, who were described as being satisfied with the "political containment of racial problems rather than their solutions" domestically or internationally ${ }^{62}$ even after President Truman had desegregated the armed forces and Brown v. Board of Education had nullified separate but equal. By 1954, Faulkner himself was making his first voyages abroad at the behest of the State Department as a cultural ambassador with the primary mission of smoothing things over. His first assignment was to an international writers' conference in São Paulo, Brazil, the purpose of which was "improving relations between the United States and the countries of South America," and he later traveled on diplomatic business through Japan, Greece, and western Europe. ${ }^{63}$ This work further closes the gap between Faulkner and 
"Faulkner," which more solidly correlates the literary and political ambitions and activities of the author with the aims of New Critics refounding democratic art on American (and southern) soil.

In 1966, four years after Faulkner's death, Malcolm Cowley attempted to offer a summative statement for his career. He claimed that Faulkner retained his "genius" as a writer late in his career despite the challenges of isolation, provincialism, and sudden stardom - all of these related to his southern origins. He admires Faulkner the most "among the great dead" because "he was the proudest man I knew. The pride made him act by his own standards, which were always difficult ones." ${ }^{64}$ Faulkner is no longer-or perhaps never was-judged by those exacting personal standards of his but rather by a knowledge community much less interested in him than in "Faulkner," the area study that his fiction demanded for his canonization, and its national politics. No doubt, his earliest scholars have effectively surveyed America's unique political situation at the beginning of the Cold War into Yoknapatawpha.

\section{Notes}

1. Lawrence H. Schwartz, Creating Faulkner's Reputation: The Politics of Modern Literary Criticism (Knoxville: University of Tennessee Press, 1988), 28.

2. Frederic Jameson, A Singular Modernity: Essay on the Ontology of the Present (New York: Verso, 2002).

3. Ibid., 36 .

4. Serge Guilbaut, How New York Stole the Idea of Modern Art: Abstract Expressionism, Freedom, and the Cold War, trans. Arthur Goldhammer (Chicago: University of Chicago Press, 1983).

5. Schwartz, Creating Faulkner's Reputation, 94.

6. See also John T. Matthews, "The Rhetoric of Containment in Faulkner," in Faulkner's Discourse: An International Symposium, ed. Lothar Hönnighausen (Tübingen: M. Niemeyer Verlag, 1989), 55-67. Matthews argues that while there are representations of the social and history in Faulkner's work, his modernist techniques, particularly in The Sound and the Fury, "conceal history's conditioning of [the novel's] apparent free play" and create work in which "History and its representation abide in a dissonant relation" (59).

7. Carl E. Pletsch, "The Three Worlds, or the Division of Social Scientific Labor, circa 1950-1975," Comparative Studies in Society and History 23 (1981): 582.

8. Ibid., 588.

9. See Suzanne W. Jones and Sharon Monteith, eds., South to a New Place: Region, Literature, Culture (Baton Rouge: Louisiana State University Press, 2002); Jon Smith and Deborah Cohn, eds., Look Away!: The U.S. South in New World Studies (Durham, NC: Duke University Press, 2004); Kathryn McKee and Annette Trefzer, "Preface: Global Contexts, Local Literatures: The New Southern Studies," American Literature 78 (2006): 677-90.

10. Thomas Borstelmann, The Cold War and the Color Line: American Race Relations in the Global Arena (Cambridge, MA: Harvard University Press, 2001), 70. For further discussion of federal civil rights policy's role in Cold War foreign policy, see also Mary Dudziak, Cold War Civil Rights: Race and Image of American Democracy (Princeton, NJ: Princeton University Press, 2000).

11. Ibid., 74-75.

12. Leigh Ann Duck, The Nation's Region: Southern Modernism, Segregation, and U.S. Nationalism (Athens: University of Georgia Press, 2006).

13. William Faulkner. "Address upon Receiving the Nobel Prize for Literature [Stockholm, December 10, 1950]," in Essays, Speeches, \& Public Letters, ed. James B. Meriwether (New York: Random House, 1965), 120.

14. William Faulkner, Selected Letters of William Faulkner, ed. Joseph Blotner (New York: Random House, 1977), 395.

15. Borstelmann notes that southern politicians generally believed there to be links between integration and communism, especially in terms of foreign policy, where the United States was having most difficulty comporting its domestic and international policy on race. Governor Herman Talmadge and Senator Richard B. Russell, both of Georgia, "believed liberals were being suckered by Moscow's Cold War rhetoric. Rather than try to satisfy Soviet demands, the United States should 
stand up proudly for its own traditions. If Communists supported racial integration, could there be any clearer sign of its immorality?" Borstelmann, The Cold War and the Color Line (108).

16. Fred Hobson, "Surveyors and Boundaries: Southern Literature and Southern Literary Scholarship after Mid-Century,” Southern Review 27 (1991): 743.

17. Michael Kreyling, Inventing Southern Literature (Jackson: University Press of Mississippi, 1998), 41.

18. Ibid., 48.

19. Louis D. Rubin Jr. and Robert D. Jacobs, eds., Southern Renascence: The Literature of the Modern South (Baltimore: Johns Hopkins University Press, 1953), vii.

20. Walter Sullivan, "Southern Novelists and the Civil War," in Rubin and Jacobs, Southern Renascence, 119.

21. Ibid., 125.

22. C. Vann Woodward, "The Irony of Southern History," in Rubin and Jacobs, Southern Renascence, 63.

23. Ibid., 78 .

24. Ibid., 79.

25. Louis D. Rubin Jr. and Robert D. Jacobs, editors' note in "Literature in the South: An Exchange of Views," in Southern Renascence, 83.

26. Ibid.

27. Howard W. Odum, "On Southern Literature and Southern Culture," in Rubin and Jacobs, Southern Renascence, 99-100.

28. John MacLachlan, "No Faulkner in Metropolis," in Rubin and Jacobs, Southern Renascence, 107.

29. Valencia Eloris Matthews, Irene Olivia Colbert Edmonds: Her Historic Tenure at Florida Agricultural and Mechanical University, 1947-1968 (electronic diss., UMI, 9608883, Florida State University), 93. Edmonds, a longtime professor at Florida Agricultural and Mechanical University, wrote the essay for one of Rubin's seminars while a master's student at Johns Hopkins. According to Matthews, Rubin faced “objections from some corners of academia" for putting Edmonds's essay in his collection. Matthews also contends that "Faulkner and the Black Shadow" "was perhaps the first perspective published from an African-American in a general study discourse examining the representation of African-Americans in the works of an acknowledged leader in modern American literature."

30. Kreyling, Inventing Southern Literature, 48.

31. Irene C. Edmonds, "Faulkner's Long Black Shadow," in Rubin and Jacobs, Southern Renascence, 192.

32. Ibid., 201.

33. Ibid., 206.

34. Kreyling, Inventing Southern Literature, 130. See also Carol Polsgrove, Divided Minds: Intellectuals and the Civil Rights Movement (New York: Norton, 2001), 4-21. Polsgrove highlights the tumult of Faulkner's life as a public intellectual from 1954 to 1958 as he argued for desegregation while ultimately maintaining that it should happen gradually in essays published in Harper's and Life and with candid comments in a March 1956 interview in the Sunday Times of London about desegregation at the University of Alabama.

35. Kreyling, Inventing Southern Literature, 132.

36. Joseph Blotner, Faulkner: A Biography, 2 vols. (New York: Random House, 1974), 1246.

37. Ibid., 1252.

38. William Faulkner, Absalom, Absalom! (New York: Vintage, 1990), 302.

39. William Faulkner, Go Down, Moses (New York: Vintage, 1990), 266.

40. Edmund Wilson, "William Faulkner's Reply to the Civil-Rights Program," review of Intruder in the Dust, by William Faulkner, The New Yorker, October 23, 1948, 222.

41. Ibid., 224.

42. Elizabeth Hardick, "Faulkner and the South Today," review of Intruder in the Dust, by William Faulkner, Partisan Review 15 (1948): 1133.

43. Cleanth Brooks, William Faulkner: The Yoknapatawpha Country (New Haven, CT: Yale University Press, 1963), 280.

44. Ibid., 288-89.

45. Jean E. Graham, "Gavin Stevens in Intruder in the Dust: Only Too Rhetorical Rhetoric?," Southern Literary Journal 22 (1990): 78-79.

46. Malcolm Cowley, The Faulkner-Cowley File: Letters and Memories, 1944-1962, (New York: Viking, 1966), 110-11.

47. Noel Polk, "Man in the Middle: Faulkner and the Southern White Moderate," in A Gathering of Evidence: Essays on William Faulkner's Intruder in the Dust, ed. Michael Gresset and Patrick Samway (Philadelphia: Saint Joseph's University Press, 2004).

48. William Faulkner, Light in August (New York: Vintage, 1990), 444.

49. Ibid., 448-49.

50. William Faulkner, Intruder in the Dust (New York: Vintage, 1995), 150. 


\section{Jordan Dominy}

51. Ibid., 150 .

52. Ibid., 151.

53. Ibid., 199.

54. Ibid., 153.

55. Joe Karaganis, "Negotiating the National Voice in Faulkner's Late Work," in Gresset and Samway, A Gathering of Evidence, 121.

56. Ibid., 124-25.

57. Polk, "Man in the Middle," 175.

58. Ibid., 176.

59. Hardwick, "Faulkner and the South Today," 1131.

60. Matthew D. Lassiter and Joseph Crespino, The Myth of Southern Exceptionalism (New York: Oxford University Press, 2010), 7.

61. Borstelmann, The Cold War and the Color Line, 68-70.

62. Ibid., 86 .

63. David Minter, William Faulkner: His Life and Work (Baltimore: Johns Hopkins University Press, 1980), 232-33.

64. Cowley, The Faulkner-Cowley File, 175. 